Linda et al./ Evaluation on the Implementation of Regional Mapping Referal System

\title{
Evaluation on the Implementation of Regional Mapping Referal System in the National Health Insurance Primary Care Services in Boyolali, Central Java
}

\author{
Linda Widyaningrum¹), Didik Tamtomo²), Arief Suryono3) \\ 1) School of Medical Records, APIKES Citra Medika Surakarta \\ ${ }^{2)}$ Masters Program in Public Health, Universitas Sebelas Maret, Surakarta \\ 3) Faculty of Law, Universitas Sebelas Maret, Surakarta
}

\begin{abstract}
Background: Badan Penyelenggara Jaminan Sosial (BPJS) Kesehatan finance preventive, promotive, curative, rehabilitative services. The referal system is needed to enhance services and to assure patient safety. The purpose of this study is to evaluate the implementation of regional mapping referal system of the national health insurance at the primary care level.

Subjects and Method: This was a qualitative study with fenomenology approach. This study was conducted at Wonosegoro I and Karanggede Community Health Centers, type C Boyolali Pandanarang district hospital, type D Boyolali Simo hospital, and Boyolali District Health Office. Data were collected by in-depth interview, direct observation, and document review.

Results: Regional mapping referal system in Boyolali district was implemented under the head of the District Health Office regulation no 440/4214/15/2014. The number of personal in charge of referal system in Wonosegoro I and Karanggede Community Health Centers, which provided inpatient care was lacking. The infrastructure and equipment were insufficient to address common diseases that consist of 155 diagnoses. The information and communication system has not connected to the referal system facilities. Telephone was used to check about the hospital bed of availability. Therefore, patient information could not be sent to the hospital beforehand.

Conclusion: The current infrastructure and equipment at Community Health Centers in Boyolali, Central Java are insufficient to support the regional mapping referal system.

Keywords: mapping, referal system, BPJS Kesehatan, primary care.

\section{Correspondence:}

Linda Widyaningrum. School of Medical Records, APIKES Citra Medika, Surakarta, Central Java. Email: linda.ningrum@ymail.com

\section{BACKGROUND}

Health insurance has been implemented since January 1, 2014 based on the mandate of the 1945 Constitution, Law No. 40 of 2004 concerning the National Social Security System (SJSN) and based on Law No. 24 of 2011 concerning the Social Insurance Administration Organization (BPJS). The purpose of establishing Law No. 24 of 2011 concerning BPJS is to achieve universal health insurance.

Improving the quality of services in accordance with the mandate of the law above is noticed because health services are the key to success in the implementation of the National Health Insurance (JKN). Financial aspects or health operational funds are regulated in the Republic of Indonesia Presidential Regulation Number 32 of 2014 concerning Management and Benefits of Funds in First-Level Health Services (Presidential Regulation No. 32/2014). The referral
\end{abstract}

e-ISSN: 2549-0281 (online) 
Journal of Health Policy and Management 1(2): 95-101 https://doi.org/10.26911/thejhpm.2016.01.02.04

system of First Level Health Facilities (FKTP) is regulated in the Regulation of the Minister of Health of the Republic of Indonesia Number 001/2012 concerning the Individual Health Service Referral System. The regulation contains the flow of patient delivery, supporting examinations, knowledge references to ensure that everyone gets quality and satisfying health services effectively and efficiently. The regulation above still has obstacles in its implementation, namely there is still a buildup of patients in certain large hospitals. One of the regencies that implemented the referral system mapping was Boyolali. Boyolali Regency is one of 35 regencies or cities in Central Java Province. Regional mapping of the referral system in Boyolali is regulated through the Regulation of the Head of the Boyolali District Health Office Number 440/4212/15/2014 concerning the Health Service Referral System in Boyolali.

Preliminary surveys conducted by reference researchers based on mapping still have gaps with the Republic of Indonesia Minister of Health Regulation Number 001/2012 and Head of Regulation of Boyolali District Health Office Number 440/4212/15 / 2014. These gaps are found in the referral mechanism in the border region based on the Boyolali District Health Office Regulation for the border region, it is permissible to leave the regency which has collaborated but based on the initial survey patients from Wonosegoro I and Karanggede community health centers were still referred to the Pandanarang district hospital.

The purpose of this study was to evaluate the implementation of the policy and management of regional mapping of service referral systems for first-level health social security management agencies in Boyolali.

\section{SUBJECTS AND METHOD}

This study was a qualitative study with a phenomenological description approach. The study was conducted at Wonosegoro I Health Center, Karanggede I Health Center, Pandanarang Boyolali Type C district hospital, Simo Boyolali district hospital type D and policy makers, namely the Boyolali District Health Office. Data collection was done by in-depth interviews, observation, and document analysis.

RESULT

1. Overview of Locations of the study Boyolali is one of 35 Regencies or Cities in Central Java Province, located between $110^{\circ}$ 22'- $110{ }^{\circ} 50$ 'East Longitude and $7^{\circ} 36^{\prime}-7^{\circ}$ 71 'South Latitude with altitudes between 75 and 1,500 meters above sea level.

\section{Overview of Regional Mapping of Referral Systems in Boyolali}

In conducting referrals, Wonosegoro 1 and Karanggede community health centers were allowed directly to Pandanarang district hospital because of its geographical location. In this case the Pandanarang district hospital acted as a level II advanced service and level III advanced services. Pandanarang district hospital Boyolali was the only type $\mathrm{C}$ hospital in Boyolali that received referrals from all type D hospitals in Boyolali and received referrals from the nearest community health center based on geographical location.

\section{Input of Implementation of Regio- nal Mapping of Referral Systems}

Based on the results of document analysis and interviews, it can be concluded that the length of work can influence the policy of regional referral system mapping that is set at the agency where the informant works. There was lack of human resources in the re- 
ferral executives especially in community health centers in Boyolali District if they had to deal with 155 diagnoses.

Observations of researchers on the facilities and infrastructure in Wonosegoro and Karanggede community health centers consisted of stethoscope, tension meter, scales, baby scales, oxygen tubes, dental instruments, minor surgery sets, obstetric devices, mercury tension meters, oxygen, medical devices, medical rehabilitation medical devices, head lamps, general medical devices, washing bottles, microscopes, general sets (lab scales, tweezers, dental equipment, dentistry, bein, and other medical devices. Non-medical facilities consist of wooden cabinets, computers, patient chairs, beds, refrigerators, fans, dispensers, printers, lights, tape recorders, flagpoles, internet, and wireless. Analysis of facilities and infrastructure documents at the community health center that researchers conducted based on the 2016 inventory list did not have medical devices that support 155 diagnoses.

Based on document analysis and interview results, the regional mapping system of the referral system in Boyolali had been regulated in the Regulation of the Head of the Boyolali District Health Office Number 440/ 4214/15/2014 concerning the Health Service Referral System in Boyolali based on the prevailing laws and regulations and had been socialized to health services in Boyolali as the basis for implementing the referral system. The regional mapping system referral policy had been socialized to health services in Boyolali.

\section{Input Implementation of Regional Mapping of Referral Systems}

Planning for the evaluation of regional mapping of the referral system in Boyolali was carried out with various stages carried out at the beginning of the BPJS health insurance.

Based on the results of observations, document analysis, interview results, and triangulation above, it can be concluded that the principle of maximizing regional referral services was still applied in Boyolali. However, it still considered the comfort and desire of the patient to be limited if the patient does not intersect with the rules of the referral system.

The results of the document analysis found the procedure for implementing administrative references in Figure 1.

The decision making process for choosing a reference place based on observations is as follows: 1) Referral decisions are made by patients or families of patients and doctors, 2) Doctors provide a choice of referral services that may be used as a place of reference, 3) Patients choose a place of reference but there are patients who are not in accordance with the mapping of the referral system. The communication process before patients are referred to is based on document analysis in the implementation of the referral system regional mapping, Boyolali health office has implemented a policy regarding the application of online referral system information and communication system applications that are applied in each health service in Boyolali. The objectives of applying the application are as follows:

1) Knowing the types and capabilities of health care facilities

2) Knowing the type and ability of medical personnel available at that time.

3) The existence of empty beds in all classes and intensive services. 
Journal of Health Policy and Management 1(2): 95-101

https://doi.org/10.26911/thejhpm.2016.01.02.04

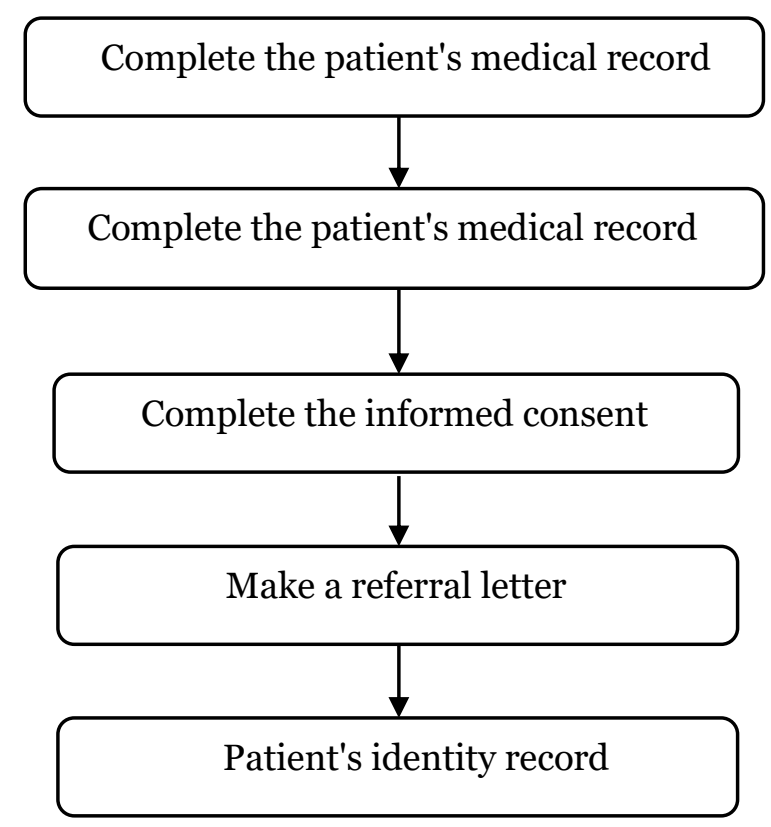

Figure 1. The procedure of implementation of patients' referrals

Monitoring of referral system mapping in Boyolali based on interviews included the following:

1) The Head of the Health Office and / or professional organization was responsible for the guidance and supervision of the implementation of the referral system mapping in accordance with the main tasks, functions and authorities. Supervision was carried out for all communitybased health service facilities, first-level health services, second-level health services and third-level health services.

2) Guidance and supervision were directed at the compliance of all parties to carry out the regional mapping of the referral system.

3) In taking administrative measures, the Health Office of Boyolali was adjusted to the authority of the Health Office in the form of verbal reprimand, written warning or revocation of the license to practice health personnel.

\section{Output of Regional Mapping of Re- ferral Systems}

The case of hospitalization with diabetes mellitus was a case that requires insulin which was not available at the community health center. Since the regional referral system was implemented, the number of patients in the Pandanarang disctrict hospital for basic cases had declined from before the regional referral system mapping was implemented. Except for basic cases that were not available for investigation.

\begin{tabular}{l}
\hline DISCUSSION \\
\hline A. Regional Mapping of Referral Sys- \\
tems for Wonosegoro I and Karang- \\
gede Health Centers \\
Pandanarang district hospital is the only type \\
C hospital in Boyolali that receives referrals \\
from all type D hospitals in Boyolali and re- \\
ceives referrals from the nearest health ser- \\
vice. In this case Pandanarang district hospi- \\
tal plays a role as a secondary level of care
\end{tabular}


and level III advanced services. This is in accordance with the Ministry of Health theory (2013), which explains that the parameters used in regional mapping of the referral system are geographic location, which considers distance and travel time in the referral service. Therefore, tiered referrals can be excluded under geographical considerations.

\section{Input of Implementation of Regio- nal Mapping of Referral Systems}

The type of service in the Puskesmas is in accordance with the Minister of Health Regulation Number 75 of 2014 concerning community health centers. Likewise with the type D advanced service, namely at the Boyolali Simo district hospital, the type of service at Simo district hospital has met the standard of having special services which have a role as a follow-up reference. However, there are still patients referred to the Pandanarang district hospital who have the role of tertiary service hospitals. This is in accordance with the Ministry of Health theory (2013), that the factors that influence regional referral system mapping are one of them is the type of service in the referral service facility.

Policies relating to regional mapping of the referral system have been socialized to officers in Boyolali health services and have been understood by health care workers. This is in accordance with Anderson (2008), which stated that the implementation of policies in the community involves various indicators such as people, funds, and infrastructure. For that policy to succeed efficiently and effectively before the formulation and ratification process is socialized to the public first. The socialization of public policies can be done by using mass media such as the internet, television, e-mail and radio, and printed media such as newspapers, magazines, banners and leaflets.

\section{The Process of Implementing Re- gional Mapping of the Referral Sys- tem}

Planning for the establishment of a regional mapping evaluation of the referral system in Boyolali is in accordance with Ministry of Health regulations (2013), regarding referral service guidelines in Indonesia.

Based on the results of the regional referral optimization interview in Boyolali, one of them was caused in terms of human resources, infrastructure and technology, which could support the achievement of a standard classification as a referral hospital. Another factor is because the patient feels closer to the place of residence even though at the same time there is no ward bed available. If inpatients patients prefer to wait in the emergency room to get an inpatient room. This condition is not yet in accordance with the objectives of the regional mapping of the referral system listed in the Ministry of Health (2013), one of which is to improve the distribution of health services.

Based on the analysis of the referral procedure it would be better if the health office made a policy related to knowledge referral. Knowledge references will add insight to medical personnel at the puskesmas in order to carry out their role as the first service facility. This is in line with the 2013 Ministry of Health theory. Factors that influence the pattern of family and helper decision making in referring patients to hospitals are predisposing factors, reinforcing factors, enabling factors, and the environment. Predisposing factors are age, education, knowledge, beliefs, values or norms, attitudes, perceptions, and previous history. Reinforcing factors are 
the behavior of other influential people such as family, peers, community leaders, and health providers. Enabling factors include geographical conditions, distance to hospitals, costs, facilities and transportation, quality and quantity of health workers, availability of tools, medicines, consumables, and blood transfusions. Environmental factors are customs or culture that support or inhibit the occurrence of decision-making processes to refer patients.

Based on the results of the above analysis in the decision making process of choosing a referral place there are still differences in choices between patients or families of patients with doctors. The patient or family does not understand the regional mapping of the referral system.

Based on document analysis, observation, and the results of the study interviews, the process of reverse referral in Boyolali can be concluded that it is necessary to develop a written policy from the health office related to the reverse referral system. With the existence of reverse referrals, it will improve the ease of access to health services, improve health services that include promotive, preventive, curative and rehabilitative access, improve the relationship between doctors and patients in the context of holistic services, and make it easier to get the drugs needed. The referral implementation mechanism has not been discussed in detail in the referral policy. The mechanism, among others, is that there is no policy on how the mechanism will be carried out after the patient returns home from an advanced hospital, and the administrative requirements in the form of a reverse referral letter are not made. This causes the reverse referral to the referring facility do not run optimally. This is not in accordance with BPJS regulations (2014).

Based on document analysis, observation, interview results, and strengthened by triangulation to nurses, it can be concluded that the use of information and communication systems that have not been connected (online) and communication has been carried out which has only asked for empty beds, will be more effective if the referral sending facility is developed and immediately applied in accordance with the policies contained in the Regulation of the Head of the Boyolali District Health Service Number 440/4214/15 /2014 concerning the Health Service Referral System in Boyolali, namely the online information system.

According to BPJS (2014), if an online information and communication system is implemented, referrers can provide information and report in advance the patient's condition. In addition, it can also ask for advice to prepare patients on the way to the referral facility by explaining the status of the patient at that time, the results of the examination and the services or actions and drugs that have been given. The available information system is developed online.

\section{Output of Implementation of Regio- nal Mapping of Referral Systems}

Since the regional mapping of the referral system has been implemented, the number of patients at Pandaranang disstrict hospital has decreased in basic cases except for basic cases that require investigation in advanced facilities. The regional mapping scheme is in accordance with the Ministry of Health 2013, that referral mapping is done in stages and takes into account the geographical location, emergencies and types of services. 


\begin{tabular}{l}
\hline REFERENCE \\
\hline Aditama TY, Wardhani LP (2014). Distribusi \\
Waktu Tunggu pada Antrian dengan \\
Menggunakan Disiplin Pelayanan \\
Prioritas; Studi Kasus Instalasi Rawat \\
Jalan di RSUD Pandanarang Boyolali \\
(Distribution of waiting time on queues \\
using priority service discipline; Case \\
study on outpatient installations at \\
Pandanarang Boyolali Hospital). Jurnal \\
Sains dan Seni Pomits, 1(1): 1-6. Retrie- \\
ved from http://digilib.its.ac.id/public- \\
/ITS-paper-32497-1209100094-paper.- \\
pdf
\end{tabular}

Agustino L (2008). Dasar-dasar Kebijakan Publik (Fundamentals of public policy). Bandung: Alfabeta.

Ali FA (2014). Analisis pelaksanaan rujukan rawat jalan tingkat pertama peserta program jaminan kesehatan nasional (JKN) di Puskesmas Siko dan Puskesmas Kalumata Kota Ternate (Analysis on the implementation of outpatient referrals to participants in the first level of national Health Care Insurance Program (JKN) in the Siko health center and Puskesmas Kalumata City of Ternate). Jurnal Ilmu Kesehatan Masyarakat UNSRAT, 5 (3). Retrieved from http://garuda.ristekdikti.go.id/documents/detail/331637
Anderson T (2008). The theory and practice of online learning. Athabasca University: AU Press Canada.

Azwar S (2010). Metode penelitian (Research methods). Yogyakarta: Pustaka Pelajar.

BPJS (2014). Panduan praktis pelayanan kesehatan (Practical guide to healthcare services). Jakarta: BPJS.

Bernard R, Paruntu L (2010). Organisasi dan manajemen struktur, perilaku dan proses komunikasi (Organization and management of structures, behaviors and processes of communication). Jakarta: Gramedia.

Bungin B (2001). Metodologi penelitian sosial (Social research methodology). Surabaya: Universitas Airlangga.

The National Social Security Council (2012). Ringkasan eksekutif kumpulan kajian dewan jaminan sosial nasional (Executive summary of the group's national social security council study). Jakarta.

Ministry of Health Republic of Indonesia (2012). Materi rapat kerja kesehatan nasional (RAKERNAS). http://www.depkes.go.id (Retrieved 2016).

Ministry of Health Republic of Indonesia (2013). Pedoman sistem rujukan (Referral system guidelines). Jakarta. 